\title{
DETERMINASI AUDIT REPORT LAG
}

\author{
Dwi Anjani ${ }^{1}$, Sigit Hermawan ${ }^{2}$, Sarwenda Biduri ${ }^{3}$ \\ Universitas Muhammadiyah Sidoarjo ${ }^{1,2,3}$
}

\begin{abstract}
This research aims to verify and provide empirical evidences about: the effect of auditor switching, going concern opinion, profit or loss of current year and company size to the audit report lag. The population of this research are the LQ45 companies listed in Indonesia Stock Exchange during the period 2011-2015. Sampling method using purposive sampling. Data collection method used is the documentation. The analysis used is multiple linear regression. The results shows that auditor switching and opini going concern does not effect to audit report lag partially, but profit or loss of current year and company size gave negative effect on audit report lag partially. Auditor switching, opini going concern, profit or loss in year going and company size gave effect on audit report lag simultaneously.

Keywords: Audit Report Lag; Auditor Switching; Opini Going Concern; Profit or Loss of current year; Company Size.
\end{abstract}

\begin{abstract}
ABSTRAK
Penelitian ini bertujuan untuk menguji dan memberikan bukti empiris tentang: pengaruh auditor switching, opini going concern, laba atau rugi tahun berjalan dan ukuran perusahaan terhadap audit report lag. Populasi pada penelitian ini adalah perusahaan LQ-45 yang terdaftar di Bursa Efek Indonesia tahun 2011 - 2015. Metode penentuan sampel menggunakan purposive sampling. Metode pengumpulan data yang dipergunakan adalah dokumentasi. Alat analisis yang digunakan adalah regresi linear berganda. Hasil penelitian menunjukkan bahwa auditor switching dan opini going concern secara parsial tidak berpengaruh terhadap audit report lag, sedangkan laba atau rugi tahun berjalan dan ukuran perusahaan secara parsial mempunyai pengaruh negatif terhadap audit report lag. Auditor switching, opini going concern, laba atau rugi tahun berjalan dan ukuran perusahaan mempunyai pengaruh secara simultan terhadap audit report lag.

Kata Kunci: Audit Report Lag; Auditor Switching; Opini Going Concern; Laba atau Rugi Tahun Berjalan; Ukuran Perusahaan.

\section{PENDAHULUAN}

Perkembangan dunia usaha di Indonesia telah mengalami perkembangan yang pesat, hal ini menimbulkan persaingan yang ketat antara perusahaan yang satu dengan perusahaan yang lainnya. Perusahaan yang terdaftar di pasar modal harus menyampaikan laporan keuangan sebagai pertanggungjawaban manajemen terhadap investor. Laporan keuangan merupakan sumber informasi yang mengkomunikasikan kegiatan transaksi keuangan bisnis kepada pihak-pihak yang mempunyai kepentingan terhadap perusahaan. Informasi yang disediakan menyangkut posisi keuangan, kinerja serta perubahan posisi keuangan suatu perusahaan yang bermanfaat dalam pengambilan keputusan ekonomi (Hermawan dan Masyhad, 2006).
\end{abstract}


Menurut Lindrianasari, dkk. (2014) Pernyataan Standar Akuntansi Keuangan (PSAK) kerangka dasar penyusunan laporan dan penyajian laporan keuangan menyatakan laporan keuangan harus memenuhi empat karakteristik kualitatif, yaitu dapat dipahami, relevan, keandalan dan dapat diperbandingkan. Selain itu perusahaan membutuhkan seorang akuntan publik untuk menjamin kebenaran sebuah laporan keuangan yang disajikan oleh perusahaan yang sesungguhnya atau tidak menyesatkan para pemakainya.

Akuntan publik bertanggungjawab dalam meningkatkan kualitas laporan keuangan dan bekerja sesuai Standar Profesional Akuntan Publik (SPAP). Mereka diharapkan cepat dan tepat waktu dalam menyelesaikan tanggungjawabnya. Semakin cepat auditor melaksanakan tugasnya maka semakin cepat pula laporan keuangan auditan tersebut dipublikasikan.

Publikasi laporan keuangan yang mengalami keterlambatan akan dianggap sebagai pertanda buruk oleh para investor. Keterlambatan dalam penyampaian laporan keuangan menunjukkan lamanya rentang waktu penyelesaian audit. Rentang waktu penyelesaian audit dari tanggal tutup buku perusahaan sampai dengan tanggal yang tercantum dalam laporan audit disebut audit report lag (Megayanti dan Budiartha, 2016).

Penelitian ini menggunakan beberapa variabel yang dianggap memberikan pengaruh terhadap audit report lag yaitu auditor switching, opini going concern, laba/rugi tahun berjalan, ukuran perusahaan. Auditor switching merupakan pergantian auditor yang dilakukan oleh suatu perusahaan. Praptika dan Rasmini (2016) menyatakan bahwa pergantian auditor berpengaruh positif terhadap audit report lag. Penugasan pertama maupun penugasan ulang merupakan salah satu pertimbangan dalam menilai risiko bawaan yaitu kecenderungan dari adanya pergantian auditor. Hal ini dapat memperpanjang audit report lag.

Opini going concern merupakan opini yang dikeluarkan oleh auditor yang menunjukkan bahwa perusahaan mampu atau tidak dalam mempertahankan kelangsungan hidupnya. Opini going concern lebih banyak ditemui ketika pengeluaran opini terlambat. Hal ini bisa dimungkinkan ketika terdapat ketidakpastian kelangsungan hidup suatu perusahaan kemudian auditor akan melakukan banyak tes dan negosiasi yang panjang agar opini going concern dapat terhindar (Astuti 2012).

Laba/rugi tahun berjalan merupakan jumlah laba atau rugi perusahaan pada tahun berjalan atau dalam satu periode. Investor sangat menyukai perusahaan yang mempublikasikan laba dibandingkan rugi karena laba merupakan good news sehingga audit report lag menjadi lebih cepat (Sumartini dan Widhiyani, 2014). Putra dan Sukirman (2014) membuktikan bahwa laba atau rugi tahun berjalan berpengaruh negatif terhadap audit report lag. Semakin tinggi laba maka semakin rendah audit report lag. Perusahaan yang cenderung menghasilkan laba maka jangka waktu penyelesaian audit semakin cepat.

Ukuran perusahaan menunjukkan besar kecil sebuah perusahaan dalam menjalankan operasinya. Perusahaan besar cenderung lebih cepat dalam menyampaikan laporan keuangan yang telah diaudit kepada publik dibandingkan dengan perusahaan kecil. Perusahaan besar mempunyai banyak tekanan dan selalu diawasi secara ketat oleh para investor, asosiasi perdagangan dan agen regulator. Puspitasari dan Latrini (2014) membuktikan bahwa ukuran perusahaan berpengaruh negatif terhadap audit report lag. Hal ini dikarenakan perusahaan 
besar memiliki sistem pengendalian internal yang baik sehingga bisa mengurangi tingkat kesalahan dalam penyusunan laporan keuangan..

Berdasarkan beberapa penelitian yang telah dilakukan tentang audit report lag menghasilkan kesimpulan yang bervariasi, maka tema penelitian ini perlu untuk dikaji kembali. Penelitian ini bermaksud untuk mempelajari lebih lanjut mengenai faktor-faktor yang mempengaruhi audit report lag. Pembahasan terkait audit report lag pada perusahaan LQ-45 karena perusahaan-perusahaan yang terdaftar dalam indeks LQ-45 termasuk dalam perusahaan yang sahamnya memiliki tingkat likuiditas dan kapitalisasi pasar yang tinggi sehingga tidak sembarang perusahaan yang dapat masuk ke dalam kriteria LQ-45.

\section{TINJAUAN PUSTAKA DAN PENGEMBANGAN HIPOTESIS}

\section{Teori Agensi (Agency Theory)}

Agency Theory menjelaskan hubungan yang terjadi antara pihak agent (pihak manajemen atau CEO perusahaan) dengan principal (pemilik perusahaan/pemegang saham). Dalam hal ini hubungan keagenan merupakan perjanjian antara satu orang atau lebih yang mempekerjakan orang lain untuk memberikan jasanya kemudian untuk pengambilan keputusan diserahkan kepada agen tersebut (Jensen dan Meckling, 1976). Namun, dalam kenyataannya kepentingan manajemen dan pemegang saham sering kali bertentangan sehingga dapat menimbulkan konflik. Untuk meminimalisir konflik tersebut maka diperlukan seorang auditor independen.

Agent (manajer) sebagai pengelola perusahaan berkewajiban memberikan informasi mengenai perusahaan kepada principal (pemilik dan investor serta pemegang saham dan kreditur) agar mengetahui keadaan perusahaan. Tetapi informasi yang disampaikan terkadang tidak sesuai dengan kondisi perusahaan yang sebenarnya. Dalam hal ini, perusahaan dapat meminta auditor untuk memeriksa lebih lanjut mengenai laba-rugi perusahaaan yang berperan penting dalam laporan keuangan.

\section{Teori Signal (Signalling Theory)}

Menurut Widosari (2012), signal adalah sebuah tindakan yang diambil oleh pihak manajemen perusahaan untuk mengetahui informasi yang akurat mengenai internal perusahaan dan prospek perusahaan di masa depan daripada pihak investor. Oleh karena itu, manajer berkewajiban untuk memberikan signal atau isyarat kepada para stakeholder mengenai kondisi perusahaan. Signal atau isyarat yang diberikan dapat berupa pengungkapan informasi akuntansi seperti publikasi laporan keuangan auditan. Perusahaan yang menyajikan laporan keuangan tepat waktu akan mendapat pandangan positif dari masyarakat, investor dan pengguna lainnya karena ketepatan waktu tersebut merupakan signal bahwa perusahaan mempunyai kinerja yang baik. Informasi yang dikeluarkan oleh perusahaan juga akan berpengaruh terhadap keputusan investasi bagi pihak pengguna.

\section{Audit Report Lag}

Menurut Ashton, dkk. (1987), "audit delay is the length of time from a company's fiscal year-end to the date of the auditors report". Berarti, audit delay atau audit report lag merupakan rentang waktu penyelesaian audit dari akhir 
tahun fiskal perusahaan (31 Desember) sampai dikeluarkannya laporan audit. Waktu penyelesaian audit dilihat dari perbedaan waktu tanggal tutup buku laporan keuangan dengan tanggal opini audit dalam laporan auditor independen. Penyediaan informasi akuntansi kepada publik akan memberikan nilai lebih apabila informasi tersebut disajikan secara tepat waktu.

Ketepatan waktu merupakan elemen penting dan pokok bagi laporan keuangan yang dibutuhkan penggunanya. Para pemakai informasi akuntansi tidak hanya perlu memiliki informasi keuangan yang relevan, tetapi informasi tersebut juga harus bersifat baru. Laporan keuangan dianggap kehilangan relevansinya ketika informasi tersebut tidak dapat mempengaruhi keputusan yang akan diambil. Jadi semakin panjang audit report lag maka perusahaan akan semakin terlambat dalam menyampaikan laporan keuangan kepada publik. Pada dasarnya tujuan dari audit laporan keuangan adalah menyajikan pendapat tentang apakah laporan keuangan perusahaan tersebut sudah menyajikan secara wajar sesuai dengan prinsip akuntansi.

\section{Auditor Switching}

Auditor Switching merupakan pergantian auditor atau kantor akuntan publik yang dilakukan oleh suatu perusahaan baik secara voluntary maupun secara mandatory. Ahmed dan Hossain (2010) menyatakan bahwa pergantian auditor merupakan putusnya hubungan antara auditor yang lama dengan perusahaan kemudian mengangkat auditor yang baru. Putusnya hubungan auditor yang lama digantikan dengan yang baru mengharuskan auditor yang baru berkomunikasi dengan auditor yang lama untuk mengidentifikasi tentang perusahaan tersebut. Setelah memahami alasan perusahaan untuk melakukan audit, kemudian auditor harus menyusun strategi pengauditan mulai dari awal dengan memahami bisnis dan industri klien tersebut.

Keputusan Ketua BAPEPAM dan LK Nomor: KEP- 310/BL/2008, menetapkan bahwa pemberian jasa audit atas laporan keuangan klien dapat dilakukan oleh Kantor Akuntan Publik paling lama untuk 6 (enam) tahun buku berturut-turut dan seorang akuntan publik paling lama untuk 3 (tiga) tahun buku berturut-turut. Klien yang mengganti auditornya tanpa alasan yang jelas, kemungkinan disebabkan oleh ketidakpuasan klien terhadap jasa yang diberikan. Pergantian auditor dapat saja diganti sebelum adanya audit laporan keuangan sehingga tidak mengganggu proses pengauditan.

\section{Opini Going Concern}

Menurut Astuti (2012) mengadopsi pernyataan IAI, 2001: SA Seksi 341 bahwa opini audit going concern adalah opini yang dikeluarkan oleh auditor untuk mengevaluasi apakah terdapat kesangsian mengenai kemampuan perusahaan untuk mempertahankan kelangsungan hidupnya. Opini audit diklasifikasikan menjadi dua macam yaitu opini audit going concern dan opini audit non going concern. Opini audit going concern meliputi opini wajar tanpa pengecualian dengan paragraf penjelas (unqualified opinion with explanatory language) dan opini tidak memberikan pendapat (disclaimer opinion). Sedangkan opini audit non going concern meliputi opini wajar tanpa pengecualian (unqualified opinion), opini wajar dengan pengecualian (qualified opinion), dan opini tidak wajar (adverse opinion). 
Masih menurut Astuti (2012) dalam pernyataan IAI, 2001: SA Seksi 341, faktor yang mempengaruhi auditor dalam menerbitkan opini audit going concern adalah:

a) Trend negatif, yaitu kerugian operasi yang berulang kali terjadi.

b) Petunjuk lain tentang kemungkinan kesulitan keuangan, seperti kegagalan dalam memenuhi kewajiban utangnya, penunggakan pembayaran deviden atau penjualan sebagian besar aktiva.

c) Masalah intern, seperti pemogokan kerja atau kesulitan hubungan perburuhan yang lain.

d) Masalah luar yang terjadi, seperti kehilangan franchise, lisensi, kehilangan pelanggan atau pemasok utama, kerugian akibat bencana alam.

\section{Laba atau Rugi Tahun Berjalan}

Laba atau rugi tahun berjalan merupakan laba atau rugi yang diperoleh dalam tahun berjalan oleh perusahaan setelah dikurangi utang pajak. Dua alasan yang menjadi penyebab audit report lag menjadi lebih panjang. Pertama, perusahaan yang melaporkan kerugian berusaha untuk menunda berita buruk tersebut, kemudian meminta auditor untuk memeriksa kembali laporan keuangannya sehingga akan menunda publikasi laporan keuangan perusahaan. Auditor juga akan berhati-hati dalam proses audit tersebut apabila kerugian perusahaan diakibatkan oleh kegagalan keuangan atau kesalahan manajemen. Tetapi jika perusahaan melaporkan laba maka berharap laporan keuangan auditan tersebut diselesaikan secepatnya sehingga berita baik tersebut dapat segera disampaikan kepada pihak-pihak yang berkepentingan (Kartika, 2011). Informasi tentang laba/rugi perusahaan dapat digunakan untuk mengevaluasi kinerja perusahaan sebelumnya, melihat risiko, tolak ukur perusahaan, menganalisa strategi perusahaan, alat pengendalian alokasi sumber daya ekonomi suatu negara, dan dasar penentuan besarnya penggunaan pajak.

\section{Ukuran Perusahaan}

Ukuran perusahaan merupakan besar kecilnya sebuah perusahaan yang dapat dilihat dari total aktiva perusahaan, nilai pasar saham, dan lain-lain. Menurut Arens, dkk. (2005), ukuran perusahaan dapat dinilai dari total aset yang dimiliki perusahaan. Aset merupakan sumber daya yang dikuasai oleh perusahaan baik yang didanai dengan modal sendiri ataupun dengan utang, merupakan hasil dari peristiwa masa lalu dan diharapkan memberikan manfaat dimasa mendatang. Apabila klien perusahaan kecil, maka cukup diaudit oleh satu atau dua orang audit dengan waktu pengerjaan audit tidak begitu lama, dan dengan honorarium audit tidak begitu besar. Namun apabila yang diaudit adalah perusahaan besar, maka dibutuhkan audit yang cukup banyak. Perusahaan yang besar akan lebih konsisten atau tepat waktu dibandingkan perusahaan kecil dalam menginformasikan laporan keuangannya disebabkan perusahaan tersebut diawasi secara ketat oleh investor, pengawas permodalan dari pemerintah dimana pihak-pihak tersebut sangat berkepentingan terhadap informasi yang termuat dalam laporan keuangan.

\section{Pengaruh Auditor Switching terhadap Audit Report Lag}

Auditor switching adalah pergantian auditor oleh suatu perusahaan klien. Menurut Arens, dkk. (2011) putusnya hubungan auditor yang lama digantikan 
dengan yang baru mengharuskan auditor yang baru berkomunikasi dengan auditor yang lama untuk mengidentifikasi tentang perusahaan tersebut. Setelah memahami alasan perusahaan untuk melakukan audit, kemudian auditor harus menyusun strategi pengauditan mulai awal dengan memahami bisnis dan industri klien tersebut. Hal ini menyebabkan auditor memerlukan waktu yang lebih lama dalam menyelesaikan proses audit. Putra dan Sukirman (2014) melakukan penelitian dengan kesimpulan bahwa auditor switching tidak berpengaruh terhadap audit report lag. Lamanya proses audit tidak dipengaruhi oleh auditor switching, hal ini disebabkan karena pergantian auditor dapat dilakukan jauh sebelum tahun tutup buku berakhir. Namun penelitian yang dilakukan oleh Praptika dan Rasmini (2016) menyatakan bahwa pergantian auditor berpengaruh positif terhadap audit report lag. Penugasan pertama maupun penugasan ulang merupakan salah satu pertimbangan dalam menilai risiko bawaan yaitu kecenderungan dari adanya pergantian auditor dapat memperpanjang audit report lag.

\section{H1 : Auditor switching berpengaruh terhadap audit report lag}

\section{Pengaruh Opini Going Concern terhadap Audit Report Lag}

Opini going concern merupakan opini yang dikeluarkan oleh auditor untuk mengevaluasi apakah terdapat kesangsian tentang kemampuan perusahaan untuk mempertahankan kelangsungan hidupnya. Semakin lama rentang waktu penyelesaian audit maka semakin tinggi kemungkinan entitas memperoleh opini audit dengan modifikasi going concern. Menurut Astuti (2012) opini going concern lebih banyak ditemui ketika pengeluaran opini terlambat. Hal ini bisa dimungkinkan ketika tedapat ketidakpastian kelangsungan hidup suatu perusahaan kemudian auditor akan melakukan banyak tes dan negosiasi yang panjang agar opini going concern dapat terhindar.

\section{H2 : Opini going concern berpengaruh terhadap audit report lag}

\section{Pengaruh Laba atau Rugi Tahun Berjalan terhadap Audit Report Lag}

Laba/rugi tahun berjalan merupakan laba atau rugi yang diperoleh dalam tahun berjalan oleh perusahaan setelah dikurangi utang pajak. Menurut Iskandar dan Trisnawati (2010) para investor akan menyukai perusahaan yang mengumumkan laba dibandingkan rugi karena dipandang berita baik/good news, sehingga pihak manajemen cenderung melaporkan tepat waktu agar investor segera mendapatkan berita baik/good news dan membuat audit report lag suatu perusahaan lebih pendek. Putra dan Sukirman (2014) membuktikan bahwa laba atau rugi tahun berjalan berpengaruh negatif terhadap audit report lag. Semakin tinggi laba maka semakin rendah audit report lag. Perusahaan yang cenderung menghasilkan laba maka jangka waktu penyelesaian audit semakin cepat. Sementara penelitian yang dilakukan oleh Kartika (2011) menyatakan bahwa laba atau rugi tahun berjalan tidak berpengaruh terhadap audit report lag karena pada saat itu tingkat perekonomian yang tidak stabil. Kemudian banyak perusahaan yang mengalami kerugian sehingga mengabaikan pelaporan keuangannya. 


\section{H3 : Laba atau rugi tahun berjalan berpengaruh terhadap audit report lag}

\section{Pengaruh Ukuran Perusahaan terhadap Audit Report Lag}

Ukuran perusahaan merupakan besar kecilnya sebuah perusahaan dapat dilihat dari beberapa segi yakni total nilai aset, total penjualan, jumlah tenaga kerja, dan lain-lain. Pada penelitian ini melihat besar kecilnya sebuah perusahaan berdasarkan total nilai aset karena total aset dianggap lebih stabil dalam menunjukkan ukuran perusahaan. Puspitasari dan Latrini (2014) membuktikan bahwa ukuran perusahaan berpengaruh negatif terhadap audit report lag yang artinya semakin besar ukuran perusahaan maka akan semakin pendek audit report lag dan sebaliknya. Hal ini dikarenakan perusahaan besar memiliki sistem pengendalian internal yang baik sehingga bisa mengurangi tingkat kesalahan dalam penyusunan laporan keuangan. Kartika (2009) juga menyatakan ukuran perusahaan berpengaruh negatif terhadap audit report lag.

\section{H4 : Ukuran perusahaan berpengaruh terhadap audit report lag}

\section{Pengaruh Auditor Switching, Opini Going Concern, Laba atau Rugi Tahun Berjalan, Ukuran Perusahaan terhadap Audit Report Lag}

Perusahaan akan melakukan pergantian auditor dengan harapan auditor baru lebih berkualitas untuk menghasilkan laporan keuangan dengan kredibilitas yang tinggi sebagai bentuk pertanggung jawaban manajemen terhadap investor. Praptika dan Rasmini (2016) menunjukkan bahwa auditor switching berpengaruh terhadap audit report lag. Perusahaan yang melakukan pergantian auditor mengakitbatkan terlambatnya penyampaian laporan keuangan yang telah diaudit. Karena auditor harus melakukan beberapa proses sebelum proses audit dimulai. Perusahaan yang mendapatkan opini going concern mengakibatkan panjangnya waktu yang dibutuhkan dalam penyelesaian audit. Astuti (2012) menemukan adanya pengaruh opini going concern terhadap audit report lag karena jika auditor semakin banyak melakukan pengujian dan manajemen juga akan melakukan negosiasi maka penyampaian laporan keuangan menjadi terlambat.

Pada perusahaan yang mempunyai laba atau rugi tahun berjalan yang tinggi cenderung akan mempercepat publikasi laporan keuangannya, karena bisa menaikkan nilai perusahaan tersebut. Putra dan Sukirman (2014) menunjukkan bahwa laba atau rugi tahun berjalan berpengaruh negatif terhadap audit report lag. Oleh karena itu, perusahaan yang memperoleh laba tinggi cenderung mengalami audit report lag yang lebih pendek. Sehingga goodnews tersebut dapat segera disampaikan kepada pihak-pihak yang berkepentingan. Perusahaan yang besar pasti memiliki pengendalian internal yang baik, semakin besar total aktiva perusahaan maka akan semakin pendek audit report lag. Kartika (2009) menunjukkan bahwa ukuran perusahaan berpengaruh negatif terhadap audit report lag. Perusahaan besar cenderung lebih cepat menyelesaikan proses audit. 
H5 : Auditor switching, opini going concern, laba atau rugi tahun berjalan, ukuran perusahaan berpengaruh terhadap audit report lag

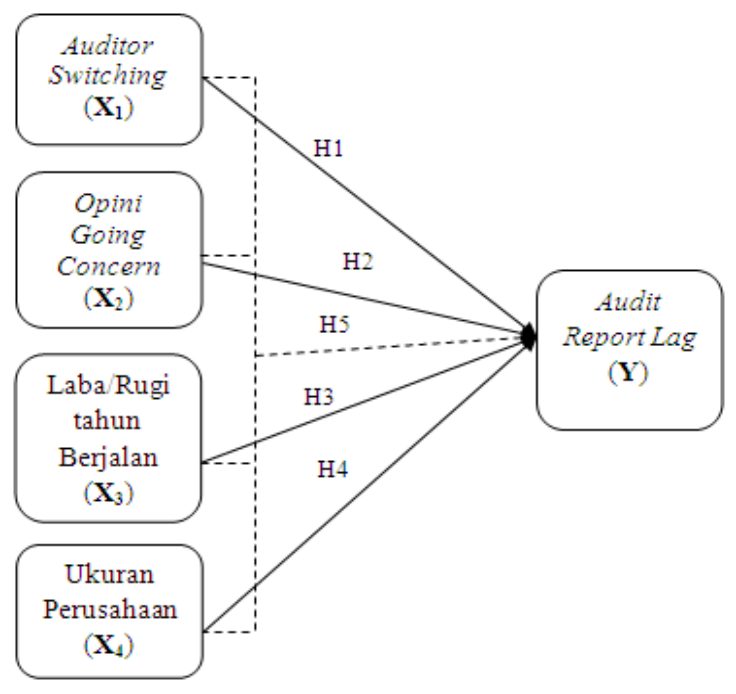

\section{Gambar 1 \\ Kerangka Konseptual}

\section{Keterangan :}

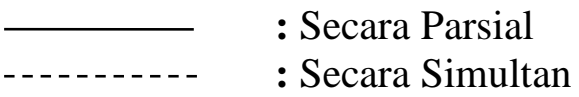

\section{METODE PENELITIAN}

\section{Jenis Penelitian}

Jenis penelitian yang digunakan adalah penelitian kuantitatif asosiatif. Menurut Sugiyono (2011) metode penelitian kuantitatif adalah metode penelitian yang berlandaskan pada filsafat positivisme, yang digunakan untuk meneliti populasi atau sampel tertentu, analisis datanya bersifat kuantitatif/statistik, yang bertujuan untuk menguji hipotesis yang telah ditetapkan. Penelitian asosiatif merupakan penelitian yang bertujuan untuk mengetahui pengaruh ataupun juga hubungan antara dua variabel atau lebih. Data yang digunakan untuk meneliti berbentuk angka atau bilangan. Penelitian ini dikatakan kuantitatif karena bertujuan untuk memberikan bukti empiris mengenai pengaruh auditor switching, opini going concern, laba atau rugi tahun berjalan dan ukuran perusahaan terhadap audit report lag.

\section{Definisi Operasional dan Pengukuran Variabel}

\section{a) Auditor Switching}

Auditor Switching adalah pergantian auditor atau kantor akuntan publik yang dilakukan oleh suatu perusahaan tersebut baik secara voluntary maupun secara mandatory. Auditor Switching diukur menggunakan variabel dummy, 
dimana jika perusahaan tersebut diaudit oleh auditor yang berbeda dari tahun sebelumnya secara sukarela ataupun wajib diberi kode 1 sedangkan jika perusahaan tersebut diaudit oleh auditor yang sama dari tahun sebelumnya atau tetap, maka diberi kode 0 (Praptika dan Rasmini, 2016).

\section{b) Opini Going Concern}

Opini going concern merupakan opini audit modifikasi yang dikeluarkan oleh seorang auditor yang menunjukkan kesangsian sebuah perusahaan mampu atau tidaknya dalam mempertahankan kelangsungan hidupnya atau bisnisnya dimasa mendatang. Variabel ini diukur menggunakan variabel dummy, dimana perusahaan yang menerima opini audit going concern yang diklasifikasikan menjadi opini wajar tanpa pengecualian dengan paragraf penjelasan (unqualified opinion with explanatory language) maupun opini tidak memberikan pendapat (disclaimer opinion) diberi kode 1 dan perusahaan yang tidak menerima opini audit going concern yang diklasifikasikan menjadi opini wajar tanpa pengecualian (unqualified opinion), opini wajar dengan pengecualian (qualified opinion), dan opini tidak wajar (adverse opinion) yang terdapat dalam laporan auditor independen, diberi kode 0 (Astuti, 2012).

\section{c) Laba atau Rugi Tahun Berjalan}

Laba atau Rugi Tahun Berjalan merupakan laba atau rugi yang diperoleh dalam tahun berjalan oleh suatu perusahaan. Variabel ini diukur menggunakan logaritma atau log natural (laba/rugi tahun berjalan). (Putra dan Sukirman, 2014).

Laba/Rugi Tahun Berjalan Perusahaan = Log Natural (Total Laba/Rugi Tahun Berjalan)

\section{d) Ukuran Perusahaan}

Ukuran Perusahaan menunjukkan besar kecilnya sebuah perusahaan tersebut. Menurut Kartika (2009) variabel ukuran perusahaan diukur berdasarkan total aktiva yang dimiliki oleh setiap perusahaan yang menjadi sampel. Dan digunakan sebagai tolak ukur skala perusahaan dengan menggunakan logaritma atau log natural (total aset). Mengukur berdasarkan total aset karena total aset lebih stabil dalam menunjukkan ukuran perusahaan dibandingkan dengan kapitalisasi pasar dan penjualan.

$$
\text { Ukuran Perusahaan = Log Natural }
$$

\section{e) Audit Report Lag}

Audit Report Lag merupakan rentang waktu penyelesaian audit antara tanggal tahun tutup buku perusahaan sampai dengan tanggal yang tercantum dalam laporan keuangan auditan. Audit report lag diukur berdasarkan jumlah hari yang diperoleh dari selisih antara tanggal tutup buku perusahaan (31 Desember) sampai dengan tanggal laporan audit yang dikeluarkan dan ditandatangani oleh KAP (Puspitasari dan Latrini, 2014).

\section{Populasi dan Sampel}

Populasi dalam penelitian ini menggunakan perusahaan yang terdaftar di Bursa Efek Indonesia sebagai perusahaan LQ-45. Pengambilan sampel dalam penelitian ini dilakukan secara purposive sampling, dengan kriteria sebagai berikut: 
a) Perusahaan yang selama 5 tahun berturut-turut dari tahun 2011 hingga tahun 2015 terdaftar dalam indeks LQ-45.

b) Perusahaan dalam indeks LQ-45 yang menggunakan mata uang rupiah dalam laporan keuangannya.

c) Perusahaan yang telah mempublikasikan dengan lengkap laporan keuangan tahunan berturut-turut dari tahun 2011-2015 dan memiliki informasi yang digunakan peneliti.

Tabel 1. Proses Seleksi Sampel

\begin{tabular}{ccc}
\hline Kriteria & umlah \\
\hline $\begin{array}{c}\text { Perusahaan yang selama 5 tahun berturut-turut dari tahun 2011 } \\
\text { hingga tahun 2015 terdaftar dalam indeks LQ-45. }\end{array}$ & 21 \\
\hline $\begin{array}{c}\text { Perusahaan dalam indeks LQ-45 yang tidak menggunakan mata } \\
\text { uang rupiah dalam laporan keuangannya. }\end{array}$ & 2 ( \\
\hline $\begin{array}{c}\text { Perusahaan yang tidak mempublikasikan dengan lengkap } \\
\text { keuangan tahunan (annual report) berturut-turut dari tahun } \\
\text { 2011-2015 dan memiliki informasi yang digunakan peneliti. }\end{array}$ & $4)$ \\
\hline Jumlah & 5 & 1 \\
\hline & 5 & 7 \\
\hline
\end{tabular}

Sumber : data yang diolah, 2017

\section{Jenis dan Sumber Data}

Jenis data yang digunakan dalam penelitian ini adalah data kuantitatif. Karena data yang dihasilkan dalam penelitian berupa angka yang berdasarkan analisis statistik. Sumber data yang digunakan adalah data sekunder. Sumber data yang digunakan peneliti adalah annual report atau laporan tahunan perusahaan dan laporan auditor independen yang terdaftar sebagai indeks LQ-45 selama periode 2011-2015 diperoleh dari Bursa Efek Indonesia.

\section{Teknik Pengumpulan Data}

Teknik pengumpulan data yang digunakan adalah teknik dokumentasi dilakukan dengan mengumpulkan data sekunder dan seluruh informasi yang terdapat dalam situs resmi www.idx.co.id. Data yang dikumpulkan dalam penelitian ini berupa laporan keuangan tahunan perusahaan LQ-45 tahun 20112015. Laporan keuangan tahunan dalam penelitian ini digunakan untuk menentukan auditor switching, opini going concern, dan audit report lag dengan melihat laporan auditor independen, menghitung laba/rugi tahun berjalan dengan melihat laporan laba rugi, dan menghitung ukuran perusahaan dengan melihat total aset pada neraca.

\section{Teknik Analisis Data}

\section{1) Statistik Deskriptif}

Statistik deskriptif memiliki tujuan untuk menganalisis data dan menghitung berbagai karakteristik data yang diteliti. Statistik deskriptif menunjukkan jumlah sampel, nilai minimum, nilai maksimum, nilai rata-rata dan standar deviasi (Ghozali, 2011). 


\section{2) Uji Asumsi Klasik}

Uji Asumsi klasik adalah sebuah persyaratan pengujian untuk menganalisis regresi linier berganda. Sebelum melakukan analisis regresi linier berganda, metode mensyaratkan untuk melakukan uji asumsi klasik guna mendapatkan hasil yang terbaik. Uji asumsi klasik yang digunakan dalam penelitian ini adalah uji normalitas, uji multikolinieritas, uji heteroskedastisitas dan uji autokorelasi (Ghozali, 2011).

3) Analisis Regresi Linier Berganda

Penelitian ini menggunakan analisis regresi linier berganda. Hal ini menunjukkan hubungan secara linier antara dua atau lebih variabel independen dengan variabel dependen. Secara statistik, ini dapat diukur dengan nilai koefisien determinasi, uji t dan uji F. Persamaan regresi linier berganda dapat dirumuskan sebagai berikut:

$$
Y=\alpha+\beta_{1} X_{1}+\beta_{2} X_{2}+\beta_{3} X_{3}+\beta_{4} X_{4}
$$

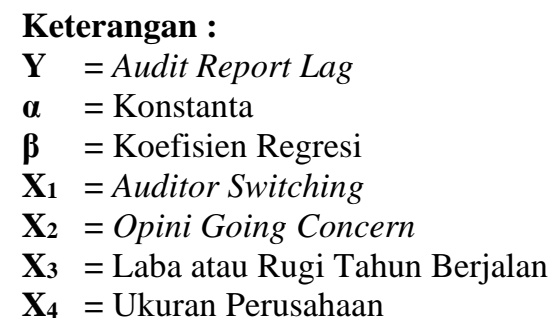

\section{4) Uji Hipotesis}

Untuk menguji hipotesis, menggunakan alat yang dinamakan regresi berganda. Dalam penggunaannya, alat uji regresi berganda terdapat beberapa analisis yang digunakan, yaitu:

\section{a) Koefisien Determinasi $\left(\mathbf{R}^{2}\right)$}

Koefisien Determinasi $\left(\mathrm{R}^{2}\right)$ digunakan untuk mengukur seberapa jauh kemampuan model dalam menerangkan variasi variabel dependen. Nilai $R^{2}$ yang kecil atau dibawah nol berarti kemampuan variabel-variabel independen dalam menjelaskan variasi variabel dependen amat terbatas. Nilai yang mendekati satu berarti variabel-variabel independen memeberikan hampir semua informasi yang dibutuhkan untuk memprediksi variasi variabel independen. (Ghozali, 2011).

\section{b) Uji F (Uji Secara Simultan)}

Uji F digunakan untuk mengukur apakah semua variabel independen yang dimasukan dalam model mempunyai pengaruh secara bersama-sama (simultan) terhadap variabel dependen. Hasil uji $\mathrm{F}$ menunjukkan variabel independen secara bersama-sama/simultan berpengaruh terhadap variabel dependen, jika p-value (pada kolom sig) lebih kecil dari level of significant yang ditentukan (sebesar 5\%) pada tabel ANOVA (Ghozali, 2011).

\section{c) Uji t (Uji Secara Parsial)}

Ghozali (2011) menyatakan bahwa uji t pada dasarnya menunjukkan seberapa besar pengaruh satu variabel independen secara individual dalam menerangkan variasi variabel dependen. Nilai dari uji thitung dapat dilihat dari $p$-value (pada kolom sig) pada masing-masing variabel independen, jika p-value lebih kecil dari level of significant 5\%, maka nilai variabel 
independen secara parsial berpengaruh signifikan terhadap variabel dependen.

\section{HASIL ANALISIS STATISTIK DISKRIPTIF}

\section{Gambaran Umum Sampel Penelitian}

Berdasarkan kriteria dalam purposive sampling maka perusahaan yang terdaftar dalam indeks LQ-45 yang memenuhi beberapa persyaratan dalam penelitian ini sebanyak 15 perusahaan, selama 5 kali publikasi laporan keuangan tahunan (2011-2015) sehingga jumlah data yang digunakan sebanyak 75 data penelitian.

Tabel 2. Daftar Perusahaan LQ-45 yang Menjadi Sampel

\begin{tabular}{|c|c|c|}
\hline $\mathbf{o}$ & Kode & Nama Perusahaan \\
\hline & AALI & Astra Agro Lestari Tbk. \\
\hline & ASII & Astra International Tbk. \\
\hline & BBCA & Bank Central Asia Tbk. \\
\hline & BBNI & Bank Negara Indonesia Tbk. \\
\hline & BBRI & Bank Rakyat Indonesia (Persero) Tbk. \\
\hline & CPIN & Charoen Pokphand Indonesia Tbk. \\
\hline & GGRM & Gudang Garam Tbk. \\
\hline & INDF & Indofood Sukses Makmur Tbk. \\
\hline & INTP & Indocement Tunggal Prakasa Tbk. \\
\hline 0 & JSMR & Jasa Marga (Persero) Tbk. \\
\hline 1 & KLBF & Kalbe Farma Tbk. \\
\hline 2 & LPKR & Lippo Karawaci Tbk. \\
\hline 3 & LSIP & PP London Sumatera Tbk. \\
\hline 4 & UNTR & United Tractors Tbk. \\
\hline 5 & UNVR & Unilever Indonesia Tbk. \\
\hline
\end{tabular}

\section{Statistik Deskriptif}

Hasil analisis statistik deskriptif yang berisi nilai minimum, maksimum, mean dan standar deviasi dapat dilihat pada tabel 3.

Tabel 3. Hasil Uji Statistik Deskriptif

\begin{tabular}{|c|c|r|r|r|r|}
\hline & & $\begin{array}{r}\text { Mini } \\
\text { mum }\end{array}$ & $\begin{array}{r}\text { Ma } \\
\text { ximum }\end{array}$ & \multicolumn{1}{c|}{$\begin{array}{r}\text { Mea } \\
\text { Deviation }\end{array}$} \\
\hline ARL & 5 & 16 & 90 & 60,6 & 19,319 \\
\hline SWITCH & 5 & 0 & 1 & 0,07 & 0,251 \\
\hline OPINI & 5 & 0 & 1 & 0,45 & 0,501 \\
\hline
\end{tabular}




\begin{tabular}{|cc|c|r|r|r|r|}
\hline GI $\quad$ LABARU & 5 & 27,16 & $7^{30,8}$ & $386^{29,0}$ & 0,99326 \\
\hline \multirow{2}{*}{ SIZE } & 5 & 29,55 & $2^{34,4}$ & $1^{31,5}$ & 1,45771 \\
\hline
\end{tabular}

Sumber : data yang diolah SPSS, 2017

Berdasarkan Tabel 3 bahwa nilai rata-rata (mean) ARL perusahaan sebesar 60,61 hari. Nilai minimum ARL sebesar 16 hari, artinya jangka waktu penyelesaian audit tercepat selama 16 hari. Nilai maximum ARL sebesar 90 hari, artinya jangka penyelesaian audit paling lama selama 90 hari.

Nilai rata-rata auditor switching 0,07 atau $7 \%$ menunjukkan bahwa perusahaan yang melakukan auditor switching selama tahun penelitian yang ditandai dengan angka 1 lebih sedikit muncul dari 75 sampel yakni 5 perusahaan yang melakukan auditor switching dan 70 perusahaan yang tidak melakukan auditor switching.

Opini going concern memiliki nilai rata-rata (mean) opini going concern 0,45 atau $45 \%$. Hal ini menunjukkan bahwa masing-masing perusahaan cenderung mendapatkan opini non going concern yakni 41 perusahaan dan 34 perusahaan yang mendapatkan opini going concern karena perusahaan sampel merupakan perusahaan yang memiliki tingkat likuidasi yang tinggi.

Laba atau rugi tahun berjalan memiliki nilai rata-rata (mean) sebesar 29,0386 dengan nilai maximum sebesar 30,87 dan nilai minimum sebesar 27,16 serta standar deviasinya 0,99326 . Berdasarkan nilai tersebut, perusahaan sampel merupakan perusahaan yang memperoleh laba.

Ukuran perusahaan memiliki nilai rata-rata (mean) sebesar 31,5609 dengan nilai maximum sebesar 34,41 dan nilai minimum sebesar 29,55 serta standar deviasinya sebesar 1,45771. Berdasarkan nilai tersebut, perusahaan sampel merupakan perusahaan yang cukup besar jika dilihat dari total aset perusahaannya.

\section{Pengujian Asumsi Klasik}

1) Hasil Uji Normalitas

Tabel 4. Hasil Uji Normalitas

\begin{tabular}{|c|c|c|}
\hline & & $\begin{array}{l}\text { Unstandar } \\
\text { dized Residual }\end{array}$ \\
\hline $\begin{array}{l}\text { Most Extreme } \\
\text { Differences } \\
\text { Kolmogorov-Smirnov Z } \\
\text { Asymp. Sig. (2-tailed) }\end{array}$ & $\begin{array}{l}\text { Mean } \\
\text { Std. Deviation } \\
\text { Absolute } \\
\text { Positive } \\
\text { Negative }\end{array}$ & $\begin{array}{r}75 \\
0,0000000 \\
17,036413 \\
90 \\
0,068 \\
0,045 \\
-0,068 \\
0,587 \\
0,881\end{array}$ \\
\hline
\end{tabular}

Sumber : data yang diolah SPSS, 2017

Berdasarkan hasil uji normalitas, menghasilkan nilai KolmogorovSmirnov sebesar 0,587 dan nilai Asymp.Sig. (2-tailed) sebesar 0,881. Maka disimpulkan bahwa data terdistribusi secara normal karena $\mathrm{P}=0,881>0,05$. 
Hasil Uji Kolmogrov-Smirnov tersebut konsisten dengan grafik normal P-Plot berikut ini :

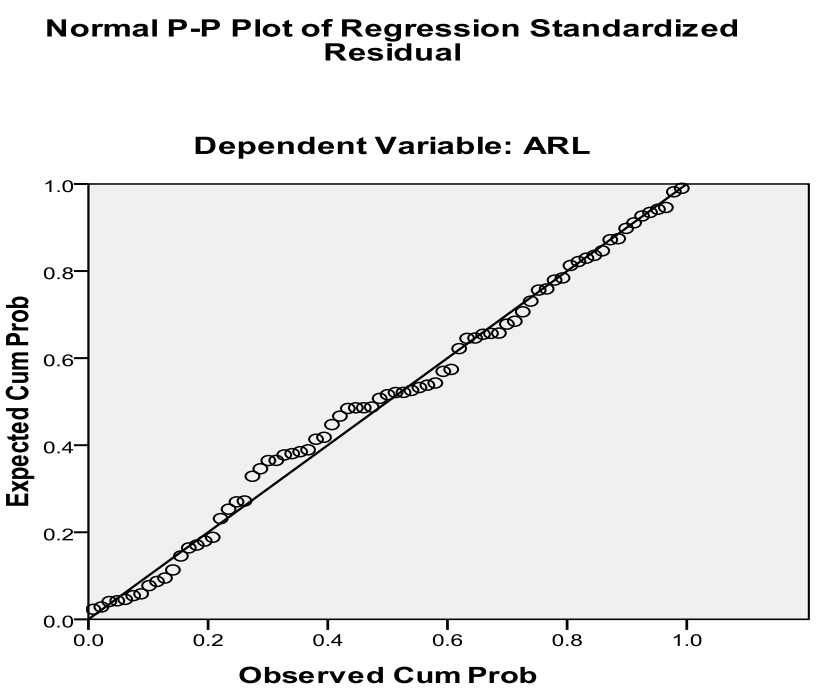

Gambar 2. Hasil Uji Normalitas dengan grafik P-Plot Sumber : data yang diolah SPSS, 2017

Grafik normal P-Plot menunjukkan pola data berdistribusi normal dengan titik-titik yang mewakili jumlah sampel dalam penelitian ini mengikuti garis diagonal.

\section{2) Hasil Uji Multikolinieritas}

Tabel 5. Hasil Uji Multikolinieritas

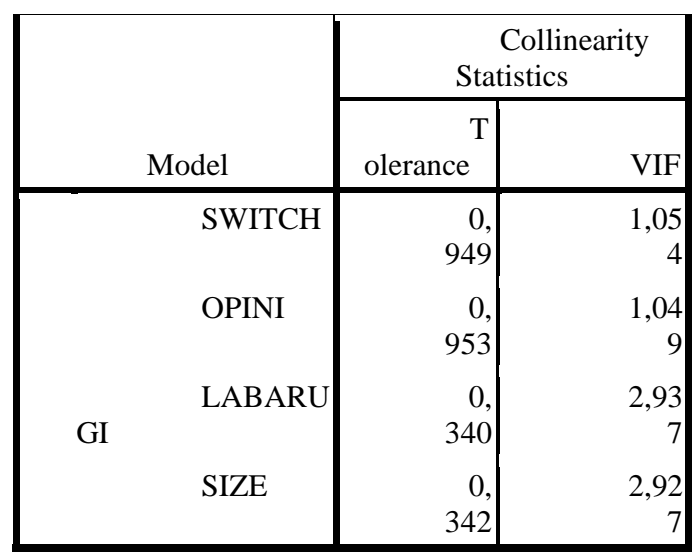

Sumber : data yang diolah SPSS, 2017

Berdasarkan hasil uji multikolinieritas, pada masing-masing variabel memiliki nilai Tolerance lebih besar dari $10 \%$ atau 0,1 yaitu: auditor switching $(0,949)$, opini going concern $(0,953)$, laba atau rugi tahun berjalan $(0,340)$, dan ukuran perusahaan $(0,342)$. Berdasarkan hasil uji multikolinieritas, pada masing-masing variabel memiliki nilai VIF kurang dari 10 yaitu: auditor switching (1,054), opini going concern $(1,049)$, laba atau rugi tahun berjalan 
$(2,937)$, ukuran perusahaan $(2,927)$. Maka dapat disimpulkan bahwa persamaan regresi tidak terjadi multikolinieritas.

\section{3) Hasil Uji Heteroskedastisitas}

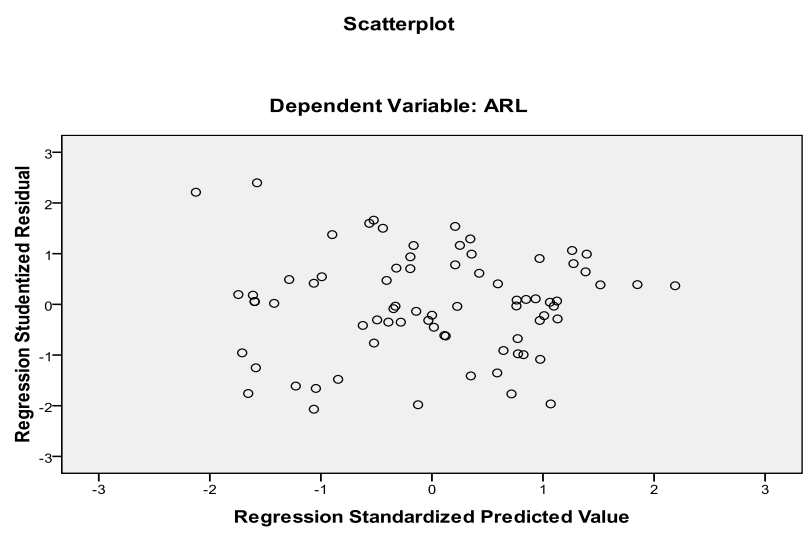

Gambar 3. Hasil Uji Scatterplot

Sumber : data yang diolah SPSS, 2017

Berdasarkan Gambar 3 menyatakan bahwa data yang terdapat pada grafik scatterplot tersebut, menyebar secara acak, tidak membentuk pola tertentu, titik-titik menyebar diatas dan dibawah angka 0 pada sumbu Y. Maka dapat disimpulkan bahwa model regresi tidak terjadi heteroskedastisitas.

\section{4) Hasil Uji Autokorelasi}

Tabel 6. Hasil Uji Autokorelasi

\begin{tabular}{|r|r|r|r|r|}
\hline $\mathrm{R}$ & Square & d R Square & $\begin{array}{r}\text { Adjuste } \\
\text { Error of the } \\
\text { Estimate }\end{array}$ & $\begin{array}{c}\text { Std. } \\
\text { Durbin- } \\
\text { Watson }\end{array}$ \\
\hline 0, & 0,77 & 0,758 & 14,1039 & 1,746 \\
878 & 1 & & 6 & \\
\hline
\end{tabular}

Sumber : data diolah SPSS, 2017

Berdasarkan hasil uji autokorelasi diketahui bahwa nilai Durbin-Watson sebesar 1,746. Dengan signifikansi 5\%, jumlah sampel (n) sebanyak 75 perusahaan dan jumlah variabel bebas $(\mathrm{k})$ sebanyak 4 , nilai $\mathrm{dl}=1,5151$ dan nilai $\mathrm{du}=1,7390$. Apabila $\mathrm{du}<\mathrm{dw}<4-\mathrm{du} 1,7390<1,746<2,261$, maka dapat disimpulkan model regresi tidak terjadi autokorelasi.

\section{Pengujian Hipotesis}

\section{1) Hasil Uji Analisis Regresi Linier Berganda}

Hasil uji regresi linear berganda disajikan pada Tabel 7. 
Tabel 7. Hasil Regresi Linier Berganda

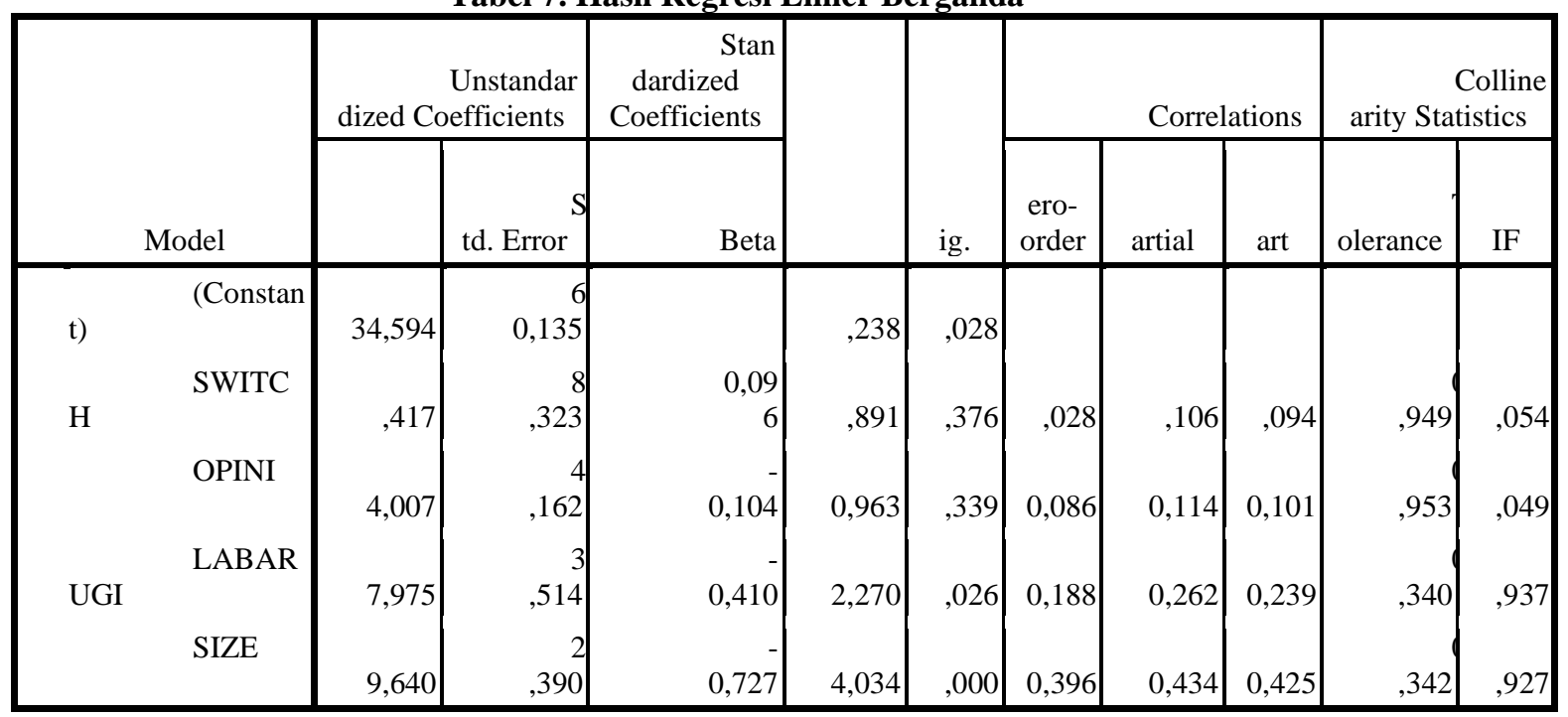

Sumber: data diolah SPSS, 2017

Berdasarkan tabel 7, dapat dibuat persamaan regresi:

$$
\begin{gathered}
Y=\alpha+\beta_{1} X_{1}+\beta_{2} X_{2}+\beta_{3} X_{3}+\beta_{4} X_{4}+e \\
Y=134,594+7,417 X_{1}-4,007 X_{2}-7,975 X_{3}-9,640 X_{4}+e
\end{gathered}
$$

Persamaan tersebut dapat diartikan sebagai berikut :

a) Nilai constant menunjukkan nilai positif sebesar 134,594 artinya jika semua variabel independen bernilai nol maka nilai variabel dependen (terikat) sebesar 134,594 dalam hal ini jika auditor switching, opini going concern, laba atau rugi tahun berjalan dan ukuran perusahaan bernilai 0 maka audit report lag sebesar 134,594 hari.

b) Nilai koefisien variabel auditor switching menunjukkan nilai positif sebesar 7,417 artinya jika nilai variabel auditor switching bernilai 1 (perusahaan melakukan auditor switching) maka akan meningkatkan audit report lag sebesar 7,417 hari.

c) Nilai koefisien variabel Opini Going Concern menunjukkan nilai negatif sebesar -4,007 artinya variabel Opini Going Concern bernilai 1 (perusahaan yang menerima opini audit going concern) akan mengurangi audit report lag sebesar 4,007 hari.

d) Nilai koefisien variabel laba atau rugi tahun berjalan menunjukkan nilai negatif sebesar -7,975 artinya setiap kenaikan 1 nilai pada variabel laba atau rugi tahun berjalan akan menurunkan nilai variabel audit report lag sebesar 7,975 hari.

e) Nilai koefisien variabel ukuran perusahaan menunjukkan nilai negatif sebesar 9,640 artinya setiap kenaikan 1 nilai pada variabel ukuran perusahaan akan menurunkan nilai variabel audit report lag sebesar 9,640 hari

\section{2) Hasil Uji Koefisien Determinasi $\left(\mathbf{R}^{2}\right)$}

Tabel 6 menunjukkan nilai koefisien determinasi pada penelitian ini sebesar 0,771 atau 77,1\%. sehingga variabel Auditor Switching, Opini Going Concern, Laba atau Rugi Tahun Berjalan dan Ukuran Perusahaan, dapat menjelaskan Audit Report Lag dan sisanya 29,9\% dijelaskan oleh variabel lain. 


\section{3) Hasil Uji F}

Tabel 8. Hasil Uji F

\begin{tabular}{|rr|r|r|r|r|r|}
\hline & Model & $\begin{array}{c}\text { Sum of } \\
\text { Squares }\end{array}$ & $\mathrm{f}$ & $\begin{array}{r}\text { Me } \\
\text { an Square }\end{array}$ & & ig. \\
\hline \multirow{2}{*}{ ion } & Regress & 6142,0 & & 153 & & \\
& & 71 & & 5,518 &, 005 &, 001 \\
\multirow{2}{*}{1} & Residua & 21477, & & 306, & & \\
& & 716 & 0 & 825 & & \\
& Total & 27619, & & & & \\
& & 787 & 4 & & & \\
\hline
\end{tabular}

Sumber : Data diolah SPSS, 2017

Berdasarkan Tabel 8 menunjukkan nilai $\mathrm{F}$ hitung sebesar 5,005 dengan nilai signifikansi sebesar 0,001 . Hal ini menunjukkan bahwa nilai sig. tersebut lebih kecil dari taraf sig. $5 \%(0,001<0,05)$ maka dapat disimpulkan model regresi memenuhi kriteria fit.

\section{4) Hasil Uji t}

Uji t digunakan untuk mengetahui apakah variabel independen secara parsial mempengaruhi variabel dependen. Berdasarkan tabel 7 maka menghasilkan uji t sebagai berikut :

\section{a. Pengaruh Auditor Switching terhadap Audit Report Lag}

Berdasarkan hasil uji hipotesis dengan menggunakan regresi linear berganda yang hasilnya dapat dilihat pada tabel 7, diperoleh hasil bahwa pengaruh auditor switching terhadap audit report lag menghasilkan thitung sebesar 0,891 dan sig. sebesar 0,376 lebih besar dari taraf signifikansi 5\% $(0,376>0,05)$ maka $\mathrm{H}_{1}$ ditolak, sehingga dapat diartikan bahwa tidak terdapat pengaruh antara variabel auditor switching terhadap audit report lag.

\section{b. Pengaruh Opini Going Concern terhadap Audit Report Lag}

Berdasarkan hasil uji hipotesis dengan menggunakan regresi linear berganda yang hasilnya dapat dilihat pada tabel 7 , diperoleh hasil bahwa pengaruh opini going concern terhadap audit report lag menghasilkan thitung sebesar -0,963 dan sig. sebesar 0,339 lebih besar dari taraf signifikansi 5\% $(0,339>0,05)$ maka $\mathrm{H}_{2}$ ditolak, sehingga dapat diartikan bahwa tidak terdapat pengaruh variabel opini going concern terhadap audit report lag.

c. Pengaruh Laba atau Rugi Tahun Berjalan terhadap Audit Report Lag

Berdasarkan hasil uji hipotesis dengan menggunakan regresi linear berganda yang hasilnya dapat dilihat pada tabel 7 , diperoleh hasil bahwa pengaruh laba atau rugi tahun berjalan terhadap audit report lag menghasilkan $t_{\text {hitung }}$ sebesar -2.270 dan sig. sebesar 0,026 lebih kecil dari taraf signifikansi $5 \% \quad(0,026<0,05)$ maka $\mathrm{H}_{3}$ diterima, sehingga dapat diartikan bahwa terdapat pengaruh negatif antara variabel laba atau rugi tahun berjalan terhadap audit report lag.

\section{d. Pengaruh Ukuran Perusahaan terhadap Audit Report Lag}

Berdasarkan hasil uji hipotesis dengan menggunakan regresi linear berganda yang hasilnya dapat dilihat pada tabel 7, diperoleh hasil bahwa 
pengaruh ukuran perusahaan terhadap audit report lag menghasilkan thitung sebesar -4.034 dan sig. sebesar 0,000 lebih kecil dari taraf signifikansi 5\% $(0,000<0,05)$ maka $\mathrm{H}_{4}$ diterima, sehingga dapat diartikan bahwa terdapat pengaruh negatif yang signifikan variabel ukuran perusahaan terhadap audit report lag.

Tabel 9. Ringkasan Hasil Hipotesis

\begin{tabular}{|c|c|c|c|}
\hline \multirow[b]{2}{*}{ o. } & \multirow[t]{2}{*}{ Hipotesis } & \multicolumn{2}{|l|}{ Perhi } \\
\hline & & tungan & asil \\
\hline & \multirow[t]{2}{*}{ Auditor switching berpengaruh terhadap audit report lag $\left(\mathrm{H}_{1}\right)$} & 0,376 & $\mathrm{H}_{1}$ \\
\hline & & $>0,05$ & ditolak \\
\hline & \multirow[t]{2}{*}{ Opini going concern berpengaruh terhadap audit report lag $\left(\mathrm{H}_{2}\right)$} & 0,339 & $\mathrm{H}_{2}$ \\
\hline & & $>0,05$ & ditolak \\
\hline & \multirow[t]{2}{*}{ Laba rugi tahun berjalan berpengaruh terhadap audit report lag $\left(\mathrm{H}_{3}\right)$} & 0,026 & $\mathrm{H}_{3}$ \\
\hline & & $<0,05$ & diterima \\
\hline & \multirow[t]{2}{*}{ Ukuran perusahaan berpengaruh terhadap audit report lag $\left(\mathrm{H}_{4}\right)$} & 0,000 & $\mathrm{H}_{4}$ \\
\hline & & $<0,05$ & diterima \\
\hline & Auditor Switching, Opini Going Concern, Laba atau Rugi tahun & 0,001 & \\
\hline & $\begin{array}{l}\text { Berjalan dan Ukuran Perusahaan berpengaruh terhadap Audit Report } \\
\text { Lag }\left(\mathrm{H}_{5}\right)\end{array}$ & $<0,05$ & diterima \\
\hline
\end{tabular}

Sumber : data yang diolah SPSS, 2017

\section{PEMBAHASAN}

\section{1) Auditor Switching berpengaruh terhadap Audit Report Lag}

Hasil uji hipotesis 1 mengenai pengaruh auditor switching terhadap audit report lag didapatkan hasil yaitu t hitung 0,891 dan sig. 0,376 lebih besar dari taraf signifikansi $5 \%(0,376>0,05)$, sehingga dapat diartikan bahwa tidak terdapat pengaruh antara variabel auditor switching terhadap audit report lag. Pergantian auditor tidak menjamin ketepatan waktu penyampaian laporan keuangan perusahaan. Auditor yang baru dalam menerima klien akan melibatkan elemen-elemen penting mengenai pemahaman industri, materialitas, risiko audit, dan pertimbangan jasa bernilai tambah. Auditor yang baru juga harus melakukan perencanaan audit, dimana diperlukan pengembangan suatu strategi audit untuk pelaksanaan audit dan penentuan lingkup audit. Pergantian auditor tidak akan mempengaruhi audit report lag, sebab penerimaan klien dan perencanaan audit dilakukan sebelum tahun fiskal klien berakhir. Putra dan Sukirman (2014) dan Austine, dkk. (2013) mendukung penelitian ini menyatakan bahwa tidak terdapat pengaruh antara auditor switching dengan audit report lag.

\section{2) Opini Going Concern berpengaruh terhadap Audit Report Lag}

Hasil uji hipotesis 2 mengenai pengaruh opini going concern terhadap audit report lag didapatkan hasil yaitu t hitung -0,963 dan sig. 0,339 lebih besar dari taraf signifikansi 5\% (0,339>0,05), sehingga dapat diartikan bahwa tidak terdapat pengaruh antara variabel opini going concern terhadap audit report lag. Opini going concern merupakan modifikasi opini yang menyatakan kesangsian tentang kemampuan perusahaan untuk mempertahankan kelangsungan hidupnya. Jenis opini audit yang diberikan oleh auditor tidak mempengaruhi cepat atau lambatnya jangka waktu audit report lag karena perusahaan yang mendapatkan pendapat selain wajar tanpa pengecualian juga 
cenderung melaporkan laporan auditnya secara tepat waktu. Pada perusahaan LQ-45 tahun 2011-2015 yang menjadi sampel penelitian ini, banyak yang melaporkan laporan keuangan tepat waktu sesuai peraturan yang ditetapkan BAPEPAM dan mendapatkan opini wajar tanpa pengecualian dengan paragraf penjelasan. Penelitian ini sesuai dengan penelitian yang dilakukan Muttaqin dan Sudarno (2011) dan Cecile (2010) yang menyatakan bahwa opini going concern tidak berpengaruh terhadap audit report lag.

3) Laba atau Rugi Tahun Berjalan berpengaruh terhadap Audit Report Lag

Hasil uji hipotesis 3 mengenai pengaruh laba atau rugi tahun berjalan terhadap audit report lag didapatkan hasil yaitu t hitung -2.270 dan sig. 0,026 lebih kecil dari taraf signifikansi $5 \%(0,026<0,05)$. Hasil ini menunjukkan bahwa terdapat pengaruh yang negatif antara variabel laba atau rugi tahun berjalan terhadap audit report lag. Laba merupakan good news bagi perusahaan sehingga akan meminta auditor untuk mempercepat publikasi laporan keuangan. Penelitian pada perusahaan LQ-45 ini menghasilkan seluruh perusahaan sampel menghasilkan laba, jadi semakin besar laba yang didapatkan oleh perusahaan maka audit report lag semakin pendek. Laba atau rugi tahun berjalan merupakan cerminan dari kinerja perusahaan yang akan menentukan kelangsungan hidup perusahaan. Perusahaan yang mendapatkan laba akan cenderung akan mempublikasikan laporan keuangan auditan tepat waktu. Putra dan Sukirman (2014) juga menyatakan bahwa terdapat pengaruh negatif antara laba atau rugi tahun berjalan dengan audit report lag.

\section{4) Ukuran Perusahaan berpengaruh terhadap Audit Report Lag}

Hasil uji hipotesis 4 mengenai pengaruh ukuran perusahaan terhadap audit report lag didapatkan hasil yaitu thitung -4.034 dan sig. 0,000 lebih kecil dari taraf signifikansi $5 \%(0,000<0,05)$. Ini dapat diartikan bahwa ukuran perusahaan berpengaruh negatif terhadap audit report lag. Penelitian ini sesuai dengan Kartika (2009) serta Puspitasari dan Latrini (2014). Semakin besar nilai aset suatu perusahaan maka semakin pendek audit report lag. Hal ini dikarenakan semakin besar perusahaan maka perusahaan tersebut memiliki sistem pengendalian intern yang baik sehingga dapat mengurangi tingkat kesalahan laporan keuangan dan proses pengauditan dapat dilakukan dengan lebih cepat. Perusahaan besar selalu diawasi oleh investor dan pengawas permodalan pemerintah, memiliki sumber daya yang lebih banyak dan dapat membayar audit fee yang lebih tinggi agar laporan audit dapat diselesaikan lebih cepat dan akurat.

5) Auditor Switching, Opini Going Concern, Laba atau Rugi Tahun Berjalan dan Ukuran Perusahaan berpengaruh secara simultan terhadap Audit Report Lag

Hasil uji hipotesis 5 mengenai pengaruh auditor switching, opini going concern, laba atau rugi tahun berjalan, ukuran perusahaan terhadap audit report lag. Didapatkan hasil nilai $\mathrm{F}$ hitung sebesar 5,005 dengan nilai signifikansi sebesar 0,001. Hal ini menunjukkan bahwa nilai sig. tersebut lebih kecil dari taraf sig. $5 \%(0,001<0,05)$ sehingga dapat disimpulkan bahwa auditor switching, opini going concern, laba atau rugi tahun berjalan dan ukuran perusahaan berpengaruh secara simultan terhadap audit report lag. Perusahaan 
yang berkualitas baik maka akan memberikan sinyal pada pengguna laporan keuangan. Sinyal tersebut dapat berupa promosi, publikasi laporan keuangan, laba rugi, opini going concern atau informasi lain yang menyatakan bahwa perusahaan tersebut lebih baik daripada perusahaan lain. Perusahaan yang menyajikan laporan keuangan tidak tepat waktu akan mendapat pandangan negatif dari penggunanya, kemudian dapat menyebabkan pergerakan harga saham tidak stabil dan mengalami penurunan harga saham. Namun sebaliknya, perusahaan yang semakin cepat proses auditnya dan mempublikasikan tepat waktu, akan mendapatkan pandangan positif dari pengguna laporan keuangan karena perusahaan tersebut mempunyai kinerja yang baik.

\section{KESIMPULAN, KETERBATASAN DAN SARAN}

Berdasarkan penjelasan sebelumnya, maka dapat disimpulkan bahwa auditor switching dan opini going concern tidak berpengaruh terhadap audit report lag. Adapun laba atau rugi tahun berjalan dan ukuran perusahaan berpengaruh negatif terhadap audit report lag. Dan secara simultan auditor switching, opini going concern, laba atau rugi tahun berjalan, ukuran perusahaan berpengaruh terhadap audit report lag.

Periode pengamatan yang digunakan dalam penelitian ini hanya 5 tahun. Penelitian ini hanya meneliti 4 variabel independen yang mempengaruhi audit report lag yaitu auditor switching, opini going concern, laba atau rugi tahun berjalan, dan ukuran perusahaan. Untuk peneliti selanjutnya, sebaiknya menggunakan populasi atau sampel dari perusahaan selain perusahaan yang terdaftar dalam indeks LQ 45. Selain itu, menambah variabel independen lain yang belum digunakan dalam penelitian ini serta menambah periode penelitian. Untuk peneliti selanjutnya, dapat mengembangkan penelitian ini dengan mengganti atau menambahkan variabel-variabel lain yang diperkirakan mampu mempengaruhi audit report lag. Untuk peneliti selanjutnya, disarankan menggunakan proksi pengukuran dengan model lain di setiap variabelnya, baik independen maupun dependen.

\section{DAFTAR PUSTAKA}

Ahmed, Alim Al Ayub dan Md. Shakawat Hossain. 2010. Audit Report Lag: A Study of the Bangladeshi Listed Companies. ASA University Review 4 (2):49-56.

Arens, Alvin A., dkk. 2005. Auditing dan Pelayanan Verifikasi. Jakarta: Salemba Empat.

Ashton, Robert H., dkk. 1987. An Empirical Analysis Of Audit Delay. Journal Of Accounting Research (Autumn) 25 (4):275-292.

Astuti, Irtani Retno. 2012. Pengaruh Faktor Keuangan Dan Non Keuangan Terhadap Penerimaan Opini Audit Going Concern. Fakultas Ekonomika dan Bisnis, Universitas Diponegoro, Semarang. 
Austine, dkk. 2013. Audit Firm Rotation and Audit Report Lag in Nigeria. IOSR Journal of Business and Management (IOSR-JBM) 12 (4).

Cecile, Yovanca. 2010. Pengaruh Debt To Total Assets Ratio, Kualitas Audit, Dan Opini Going Concern Terhadap Audit Report Lag Pada Perusahaan Manufaktur Yang Terdaftar Di Bursa Efek Indonesia. Fakultas ekonomi, Universitas sumatera utara, Medan.

Ghozali, Imam. 2011. Aplikasi Analisis Multivariat dengan Program IBM SPSS 19. Semarang: Badan Penerbit Universitas Diponegoro.

Hermawan, Sigit dan Masyhad. 2006. Akuntansi untuk Perusahaan Jasa dan Dagang. Yogyakarta: Graha Ilmu.

Iskandar, Meylisa Januar dan Estralita Trisnawati. 2010. Faktor-Faktor Yang Mempengaruhi Audit Report Lag Pada Perusahaan Yang Terdaftar Di Bursa Efek Indonesia Jurnal Bisnis Dan Akuntansi 12 (3):175-186.

Jensen, Michael C. dan William H. Meckling. 1976. Theory of the Firm: Managerial Behavior, Agency Costs and Ownership Structure. Journal of Financial Economics 3 (4):305-360.

Kartika, Andi. 2009. Faktor-Faktor yang Mempengaruhi Audit Delay di Indonesia (Studi Empiris pada Perusahaan-Perusahaan LQ-45 yang Terdaftar di Bursa Efek Jakarta). Jurnal Bisnis dan Ekonomi 16 (1):1-17.

---. 2011. Faktor-Faktor Yang Mempengaruhi Audit Delay Pada Perusahaan Manufaktur Yang Terdaftar Di BEI. Dinamika Keuangan dan Perbankan 3 (2):152-171.

Lindrianasari, dkk. 2014. Pengaruh Subsidiaries, Audit Complexity, Dan Opini Auditor Independen Terhadap Audit Report Lag.

Megayanti, Putu dan I Ketut Budiartha. 2016. Pengaruh Pergantian Auditor, Ukuran Perusahaan, Laba Rugi dan Jenis Perusahaan Pada Audit Report Lag. E-Jurnal Akuntansi Universitas Udayana 14 (2):1481-1509.

Muttaqin, Ariffandita Nuri dan Sudarno. 2011. Analisis Pengaruh Rasio Keuangan dan Faktor Non Keuangan terhadap Penerimaan Opini Audit Going Concern (Studi Empiris pada Perusahaan Manufaktur di Bei Tahun 2008-2010). Jurnal Akuntansi \& Auditing 7 (2).

Praptika, Putu Yulia Hartanti dan Ni Ketut Rasmini. 2016. Pengaruh Audit Tenure, Pergantian Auditor Dan Financial Distress Pada Audit Delay Pada Perusahaan Consumer Goods. E-Jurnal Akuntansi Universitas Udayana 15 (3).

Puspitasari, Ketut Dian dan Made Yeni Latrini. 2014. Pengaruh Ukuran Perusahaan, Anak Perusahaan, Leverage, Dan Ukuran Kap Terhadap Audit Delay. E-Jurnal Akuntansi Universitas Udayana 8 (2):283-299.

Putra, Angga Brillian Susetyo dan Sukirman. 2014. Opini Auditor, Laba atau Rugi Tahun Berjalan, Auditor Switching dalam Memprediksi Audit Delay. Accounting Analysis Journal 3 (2):187-193. 
Sugiyono. 2011. Metode Penelitian Kuantitatif, Kualitatif dan R\&D. Bandung: CV. Alfabeta.

Sumartini, Ni Komang Ari dan Ni Luh Sari Widhiyani. 2014. Pengaruh Opini Audit, Solvabilitas, Ukuran KAP dan Laba Rugi pada Audit Report Lag. E-Jurnal Akuntansi Universitas Udayana 9 (1):392-409.

Widosari, Shinta Altia. 2012. Analisis Faktor-Faktor Yang Berpengaruh Terhadap Audit Delay Pada Perusahaan Manufaktur Di Bursa Efek Indonesia Tahun 2008-2010. Fakultas Ekonomika dan Bisnis, Universitas Diponegoro, Semarang.

Www.idx.co.id 